\title{
Pelagic bacteria and phytoplankton in oceanic waters near the Canary Islands in summer
}

\author{
Antonio Bode ${ }^{1, *}$, Susana Barquero ${ }^{1}$, Manuel Varela1 ${ }^{1}$ Jose G. Braun ${ }^{2}$, \\ Demetrio de Armas ${ }^{3}$
}

\author{
${ }^{1}$ Instituto Español de Oceanografía, Centro Oceanográfico de A Coruña, Apartado 130, Muelle de Animas s/n, \\ 15080 A Coruña, Spain \\ ${ }^{2}$ Universidad de La Laguna, Depto. Biología Marina, C. Astcofisico F. Sánchez s/n, 38206 La Lagune, Spain \\ ${ }^{3}$ Instituto Español de Oceanografía, Centro Oceanográfico de Tenerife, Apartado 1373, Carretera San Andrés, \\ 38120 Sta. Cruz de Tenerife, Spain
}

\begin{abstract}
Bacterial abundance, biomass and heterotrophic activity along with hydrographic and phytoplankton variables were measured in waters surrounding the Canary Islands during Cruise BIOCAN-98 in September 1998. Three distinct oceanographic zones, defined using temperature and phytoplankton biomass concentrations, were studied. Zone A, located NW of La Palma Island, was characterized by the presence of alternating cold and warm eddies, and generally low phytoplankton biomass. Zone B was located beween La Palma and Tenerife islands and showed a predominance of cold-core eddies and higher phytoplankton concentrations than Zone A. All stations occupied in the eastern part of the Canary Islands were grouped in Zone $\mathrm{C}$ and were characterized by relatively low surface temperature $\left(<22^{\circ} \mathrm{C}\right)$ and high phytoplankton biomass. The vertical structure of the upper water column in these zones was indicative of relatively low mixing in stations of Zones A and B, while stations of Zone $\mathrm{C}$ displayed characteristics of frequent mixing events. Phytoplankton biomass showed deep relative maxima between 40 and $100 \mathrm{~m}$ at all stations. These maxima were shallower and more marked at stations with colder waters near the surface. Coccoid cyanobacteria were significantly correlated with chlorophyll $a$ and reached abundances of up to $10^{4}$ cells ml ${ }^{-1}$ in subsurface maxima. Heterotrophic bacteria were generally more abundant near the surface, and varied between 1.1 and $5.9 \times 10^{5}$ cells $\mathrm{ml}^{-1}$ in the upper $100 \mathrm{~m}$. Bacterial abundance between 100 and $300 \mathrm{~m}$ was approximately constant. Bacterial production, estimated by leucine incorporation, was not correlated with bacterial abundance or chlorophyll $a$, and displayed relative maxima between 80 and $90 \mathrm{~m}$ depth but also near the surface. There were no significant differences in mean values of abundance of cyanobacteria and heterotrophic bacteria between the oceanographic zones considered, but bacterial production and growth rates were significantly higher in Zone B. Using empirical conversion factors determined during the study, we estimated bacterial production values integrated in the upper $100 \mathrm{~m}$ that varied between 15 and $289 \mathrm{mg} \mathrm{C} \mathrm{m}^{-2} \mathrm{~d}^{-1}$, with population generation times between 2 and $25 \mathrm{~d}$. Taking into account phytoplankton biomass and primary production values, our results suggest that pelagic bacteria are able to consume dissolved organic carbon in excess of the amount produced in situ by phytoplankton in the upper surface waters of this region.
\end{abstract}

KEY WORDS: Bacterial production - Bacterial abundance $\cdot$ Phytoplankton biomass - Primary production · Central Eastern Atlantic Resale or republication not permitted without written consent of the publisher

\section{INTRODUCTION}

Pelagic bacteria are a major component of biomass in oceanic oligotrophic systems (Cho \& Azam 1990, Binder et al. 1996, Carlson et al. 1996). Heterotrophic

*E-mail: antonio.bode@co.ieo.es bacteria represent a major pathway for the flux of dissolved organic matter (Cho \& Azam 1988, Cole et al. 1988, Simon et al. 1992, Ducklow 1993, Carlson et al. 1996), while coccoid cyanobacteria may account for an important fraction of nanophytoplankton biomass ( $\mathrm{Li}$ 1995, Binder et al. 1996). The production of heterotrophic bacteria in aquatic systems is related generally to

๑) Inter-Research 2001 
phytoplankton biomass and primary production (Cole et al. 1988, White et al. 1991). Earlier studies suggested that roughly half of particulate primary production was processed by bacteria (e.g. Cole et al. 1988), but now the large variability in the degree of coupling between bacterial and phytoplankton productivity in different oceanic systems is well documented (Simon et al. 1992, Ducklow 1993, Li et al. 1993, Carlson et al. 1996, Head et al. 1996, Jones et al. 1996, Barquero et al. 1998, Gasol et al. 1998). Bacteria take up dissolved organic substrates that are known to form a substantial fraction of dissolved carbon in the ocean surface waters, and are thereby expected to play a major role in the biogeochemistry of the upper ocean (Toggweiler 1989). Recent studies indicate that bacteria of oligotrophic ocean areas may consume dissolved organic carbon in excess of primary production, producing imbalances in the carbon budgets of these areas (del Giorgio et al. 1997, Duarte \& Agustí 1998). Bacteria from oligotrophic regions (Carlson \& Ducklow 1996, Gasol et al. 1998) display lower conversion efficiencies of the consumed dissolved carbon than bacteria from coastal and eutrophic regions (Kroer 1993, Gasol et al. 1998), suggesting major losses of organic carbon through bacterial respiration in oligotrophic areas. However, whether there are extra sources of the required dissolved organic matter to fuel bacterial metabolism or simply periods when primary production and respiration are uncoupled in open-ocean waters is still a matter of debate (Kirchman 1997, Williams 1998).

The eastern Atlantic waters around the Canary Islands display characteristics of oligotrophic systems. A seasonal thermocline at depths from 50 to $120 \mathrm{~m}$ separates low-nutrient low-chlorophyll surface waters from deep nutrient-rich waters for most of the year (de León \& Braun 1973, Braun et al. 1976, 1990, Braun 1980, Braun \& Real 1984, 1986). Consequently, phytoplankton biomass and primary production are low except for a short bloom after winter mixing (de León \& Braun 1973, Braun 1980). Local examples of relatively productive areas near the islands have been reported (Real et al. 1981, Braun \& Real 1984, Arístegui et al. 1989, Fernández de Puelles \& Braun 1989, Arístegui 1990, Ojeda 1996). In addition, several types of mesoscale eddies have been related to nutrient enrichment in the surface layer or to the transport of phytoplankton-rich patches from the nearby upwelling in the African shelf, causing local accumulations of phytoplankton (Arístegui et al. 1997). Wind stress and flow perturbations of the Canary current caused by the islands are the main mechanisms involved in the formation of these eddies (Arístegui et al. 1989, 1994, 1997).

Phytoplankton biomass was not related to zooplankton abundance or biomass during the relatively short productive periods in these waters (Fernández de
Puelles \& Braun 1989), although significant positive correlations between chlorophyll and zooplankton biomass suggested an effective grazing control for most of the stratified period (Arístegui 1990). Estimations of zooplankton grazing rates suggested that zooplankton could account for more than $90 \%$ of daily particulate primary production (Braun 1974, 1981, Fernández de Puelles \& Braun 1996). Also, Hernández-León (1986) and Hernández-León \& Torres (1997) reported a significant role of zooplankton in the remineralization of particulate organic matter in Canarian waters. On the other hand, there are indications that bacteria and microheterotrophs may be significant contributors to carbon fluxes in this region. Ballesteros (1994) showed than mean bacterial abundances varied seasonally between 2.4 and $7.7 \times 10^{5}$ cells $\mathrm{ml}^{-1}$, while bacterial biomass greatly exceeded phytoplankton biomass during summer. As in other oceanic environments, small phytoplankton cells $(<10 \mu \mathrm{m})$ account for a large fraction of phytoplankton biomass and production (Braun \& Real 1981, Braun et al. 1985), but there are few measurements of picophytoplankton biomass in this area (Li 1995, Head et al. 1996, Zubkov et al. 1998). The relatively high zooplankton grazing rates may be associated with the release of dissolved organic matter from phytoplankton (Jumars et al. 1989). Such dissolved materials may be taken up by bacteria and other microheterotrophs. Arístegui \& Montero (1995) measured relatively high respiration rates in planktonic microbial communities compared to those of zooplankton of the region (Hernández-León 1987, 1988, Hernández-León \& Miranda-Rodal 1987), which suggests that bacteria may account for a significant fraction of the total oxygen consumption and carbon flow. As far as we know, there are no available measurements of bacterial production in oceanic waters around the Canary Islands to test this hypothesis, since there is but limited information on pelagic bacteria in the region (Ballesteros 1994, Li 1995, Head et al. 1996).

In this study we describe bacterioplankton abundance, biomass and production values measured in different oceanographic zones around the Canary Islands in September 1998. These measurements are related to phytoplankton composition, biomass and primary production values to obtain estimates of the importance of bacterioplankton in carbon cycling in the upper layer of this region of the Atlantic Ocean.

\section{MATERIALS AND METHODS}

Water-column temperature, salinity and fluorescence were recorded at 156 stations around the Canary Islands during the BIOCAN-98 cruise in September 1998 (Fig. 1). A CTD Mark-III probe with fluo- 


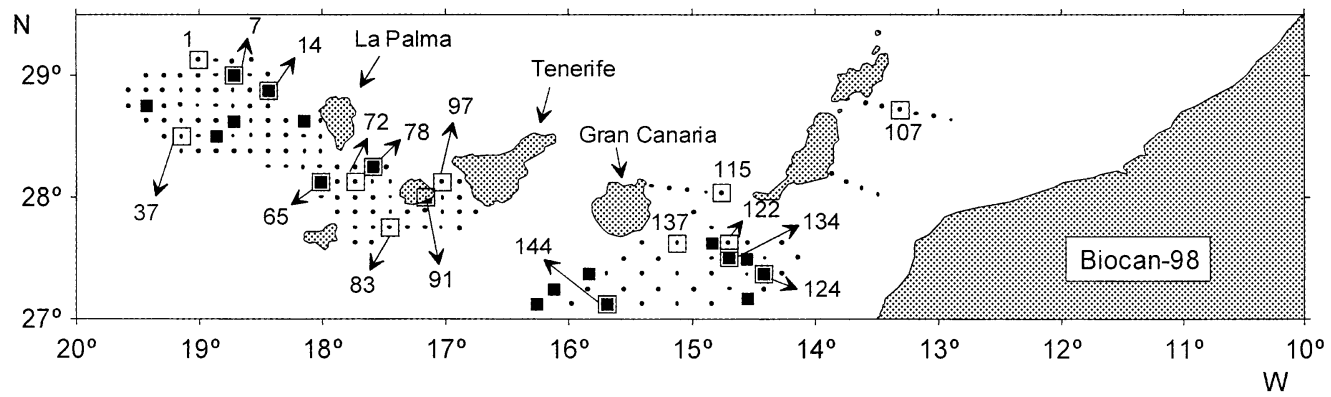

Fig. 1. Map of sampling stations during BIOCAN-98 cruise. Dots: CTD stations; numbered open squares: stations where bacterial samples were collected; black squares: stations were phytoplankton samples were collected and primary production was measured

rometer attached to a 121 Niskin-bottle rosette was employed. Water, phytoplankton and bacteria samples were collected at 5 to 9 depths between the surface and $300 \mathrm{~m}$ depth at 17 stations (Fig. 1). Water-column stratification for each plankton station was determined using the depths of the main discontinuities of $\sigma_{\mathrm{t}}$ profiles in the upper $100 \mathrm{~m}$. Three water layers (p1, p2 and p3) were revealed, corresponding to differences in $\sigma_{t}$ values $>0.02$ at $1 \mathrm{~m}$ depth intervals.

Chlorophyll a concentration ( $\mathrm{chl} \mathrm{a}$ ) was determined by the spectrophotometric method (Parsons et al. 1984) in acetone extracts of phytoplankton collected after filtration of up to $4 \mathrm{l}$ of water onto Whatman GF/F filters at selected stations (Fig. 1). The measured chlorophyll values were used to calibrate the fluorescence measured by the fluorometer of the CTD (Fig. 2). Primary production rates (PP) were measured in $125 \mathrm{ml}$ of water from 5 depths at selected stations which were inoculated with $4 \mu \mathrm{Ci}$ (148 kBq) $\mathrm{NaH}^{14} \mathrm{CO}_{3}$ and incubated on board at surface-water temperature for up to $4 \mathrm{~h}$ at midday. The irradiance equivalent to the original depth of the samples was simulated using a neutral density screen. Two light bottles and one dark bottle from each depth were incubated. Incubations were terminated by filtration onto Whatman GF/F filters. The filters were then treated with $5 \% \mathrm{HCl}_{\text {, scintilla- }}$ tion cocktail was added, and radioactivity was then counted using a liquid scintillation counter.

Eukaryotic phytoplankton species $(>8 \mu \mathrm{m})$ were identified in Lugol-preserved samples under an inverted microscope. The abundance of coccoid cyanobacteria (CB) and heterotrophic bacteria (HB) was determined in samples preserved with glutaraldehyde ( $5 \%$ final concentration) using the method of Porter \& Feig (1980). Ten millilitres of each sample were filtered on board ship onto $0.2 \mu \mathrm{m}$ black, polycarbonate, membrane filters and stained with DAPI (4'-6-diamidino-2phenylindole) for $5 \mathrm{~min}$. The filters were mounted with low-fluorescence oil on microscope slides and stored frozen. Bacteria were counted using ultraviolet light in an epifluorescence microscope (Olympus BH-2). Cyanobacteria were counted in the same slides observed under blue light and were distinguished from heterotrophic bacteria by their emission of yelloworange autofluorescence. Bacterial cellular carbon was estimated from biovolumes using the empirical equation of Norland et al. (1987) for bacteria ranging from 0.001 to $0.5 \mu^{3}$ :

$$
C=0.09 B V^{0.9}
$$

where $C$ is the carbon content $\left(\mathrm{pg} \mathrm{C} \mathrm{cell}^{-1}\right)$ and $B V$ is the bacterial biovolume $\left(\mu^{3}\right.$ cell $\left.^{-1}\right)$. Bacterial biovolumes were computed from measurements of bacterial dimensions using a graduated bar coupled to the microscope eyepiece. Cocci were considered as spheres and rods as cylinders. The mean biovolume of bacteria in this study was $0.16( \pm 0.25 \mathrm{SD}) \mu \mathrm{m}^{3}$ cell $^{-1}$ ( $\mathrm{n}=587$ ), and the resulting carbon content was 17 ( $\pm 26 \mathrm{SD})$ fg C cell ${ }^{-1}$.

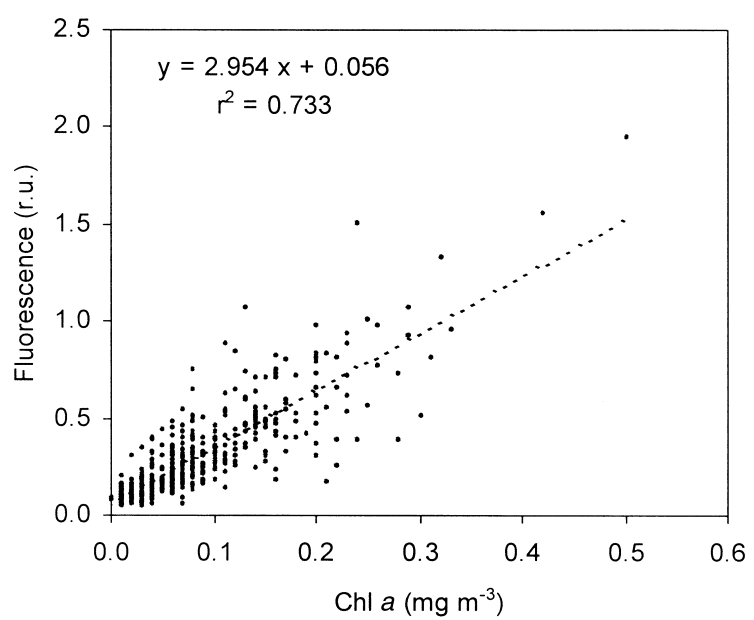

Fig. 2. Relationship between in situ fluorescence (r.u. = relative units) measured with fluorometer attached to the rosette and chl a concentration determined in acetone extracts. Coefficients of the regression line and determination coefficient $\left(\mathrm{r}^{2}\right)$ are indicated 


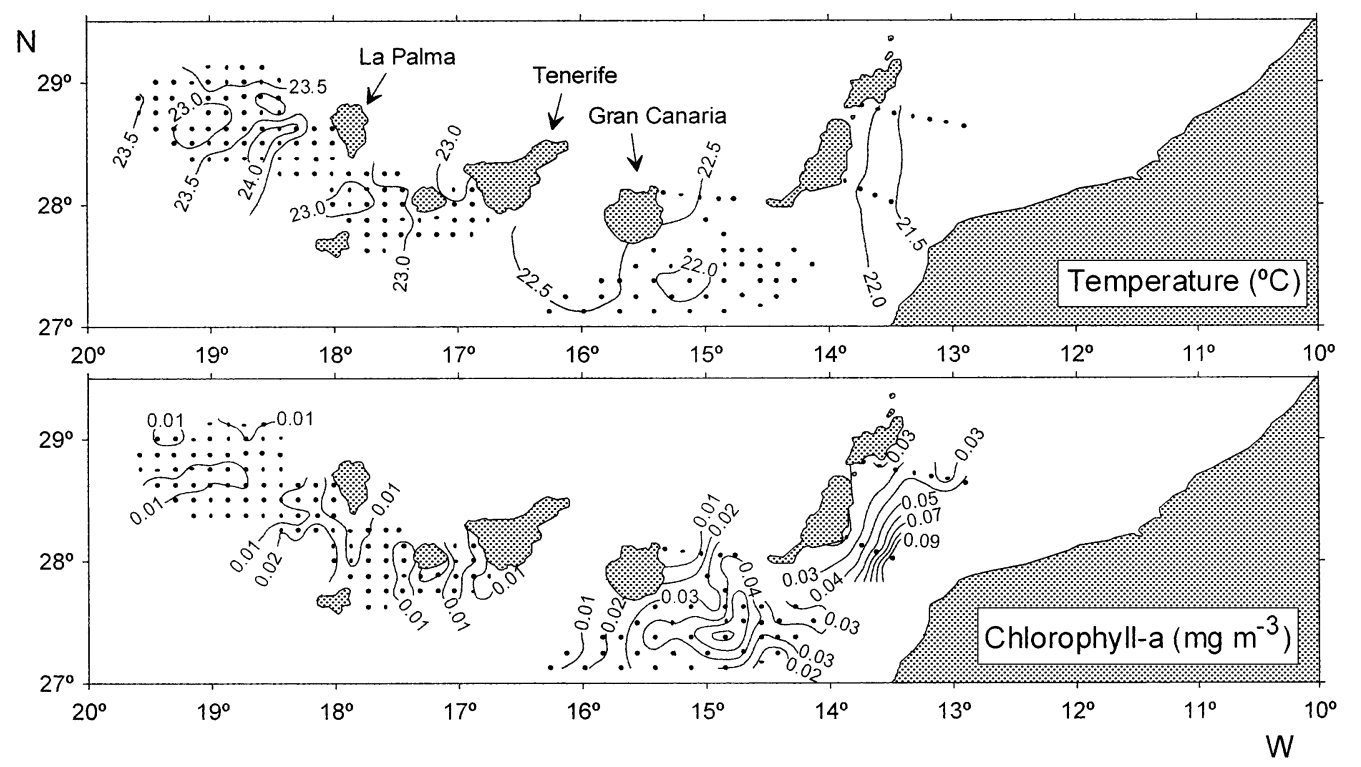

Fig. 3. Distribution of surface temperature and chl a concentration in the study area

Production of heterotrophic bacteria (PBact) was estimated by ${ }^{3} \mathrm{H}$-leucine incorporation, using the method described by Kirchman (1993), substituting the final filtration of bacteria by centrifugation (Smith \& Azam 1992). Four $1 \mathrm{ml}$ aliquots of water samples from each depth were inoculated with ${ }^{3} \mathrm{H}$-leucine to a final concentration of $150 \mathrm{nM}$ and incubated for $30 \mathrm{~min}$ on board ship in $1.5 \mathrm{ml}$ Eppendorf vials at a temperature equivalent to that of the surface water temperature (mean $\pm \mathrm{SD}=23.8 \pm 3.3^{\circ} \mathrm{C}, \mathrm{n}=15$ ). In addition, two $1 \mathrm{ml}$ controls killed with trichloroacetic acid (TCA, $5 \% \mathrm{w} / \mathrm{v}$ final concentration) were incubated for each depth. Incubations were terminated by the addition of $5 \%$ TCA to the incubation vials. Dissolved leucine was removed from the incubation vials by repeated washing with $5 \%$ TCA and successive centrifugation (12000 rpm, $10 \mathrm{~min}$ ). Scintillation cocktail (Ultima $\mathrm{X}$-Gold, Packard) was added to the vials and radioactivity was measured in a liquid scintillation counter. The mean $( \pm \mathrm{SD})$ coefficient of variation of the radioactivity measurements between the 4 replicates for each sample was $16 \pm 7 \%$ ( $\mathrm{n}=76$ samples). The conversion factors between leucine incorporation and cell growth or carbon production were determined experimentally on board at 5 stations by the procedures indicated in Bjørnsen \& Kuparinen (1991) and Kirchman \& Ducklow (1993). For each experiment, $200 \mathrm{ml}$ of surface water were diluted in $1000 \mathrm{ml}$ of $0.2 \mu \mathrm{m}$ filtered seawater and incubated at room temperature for $32 \mathrm{~h}$. Every $4 \mathrm{~h}$, aliquots of this culture were removed for the determination of bacterial abundance and leucine incorporation rates by the described procedures.

\section{RESULTS}

\section{Oceanographic zones and phytoplankton}

Surface temperature and chlorophyll a concentrations allowed the distinction of 3 main zones in the study area (Fig. 3). Zone A, located to the west of La Palma Island in the NW part of the Canarian Archipel-

Table 1. Mean $( \pm \mathrm{SD})$ surface chlorophyll a concentration ( $\left.\mathrm{chl} a_{1} \mathrm{mg} \mathrm{m}^{-3}\right)$, depth-integrated chl a $(0$ to $100 \mathrm{~m}$ and 0 to $150 \mathrm{~m}$ depth, $\mathrm{mg} \mathrm{m}^{-2}$ ) and primary production ( 0 to $100 \mathrm{~m}$ depth, $\left.\mathrm{PP}, \mathrm{mg} \mathrm{m}^{-2} \mathrm{~h}^{-1}\right)$. n: number of samples. SNK: means with different letters are significantly different at $\mathrm{p}<0.05$ level (Student-Newman-Keuls test)

\begin{tabular}{|c|c|c|c|c|c|c|c|c|c|c|c|}
\hline \multirow{2}{*}{ Zone } & \multicolumn{3}{|c|}{ Surface chl a } & \multicolumn{2}{|c|}{$100 \mathrm{~m}$-integrated chl $a$} & \multicolumn{3}{|c|}{150 m-integrated chl a } & \multicolumn{3}{|c|}{100 m-integrated PP } \\
\hline & Mean $\pm \mathrm{SD}$ & (n) & SNK & Mean $\pm \mathrm{SD}$ & $\mathrm{n}$ SNK & Mean $\pm \mathrm{SD}$ & $\mathrm{n}$ & SNK & Mean $\pm \mathrm{SD}$ & $\mathrm{n}$ & SNK \\
\hline A & $0.02 \pm 0.01$ & $(20)$ & $\mathrm{a}$ & $6.1 \pm 1.2$ & (20) a & $7.9 \pm 1.7$ & $(20)$ & $\mathrm{a}$ & $26.2 \pm 34.2$ & (6) & $\mathrm{a}$ \\
\hline B & $0.04 \pm 0.01$ & (9) & $\mathrm{b}$ & $7.8 \pm 1.4$ & (9) & $9.8 \pm 1.4$ & (9) & $\mathrm{b}$ & $17.8 \pm 3.0$ & (3) & $\mathrm{a}$ \\
\hline $\mathrm{C}$ & $0.05 \pm 0.02$ & (36) & $\mathrm{b}$ & $10.4 \pm 3.1$ & (36) b & $11.3 \pm 2.7$ & (36) & $\mathrm{b}$ & $28.2 \pm 11.2$ & (9) & $\mathrm{b}$ \\
\hline Total & $0.04 \pm 0.02$ & (65) & & $8.7 \pm 3.1$ & (64) & $10.0 \pm 2.7$ & (65) & & $25.8 \pm 20.4$ & (18) & \\
\hline
\end{tabular}


ago, was characterised by the presence of mesoscale eddies of alternating cold and warm cores. Chlorophyll concentrations at the surface were patchy but never reached $0.02 \mathrm{mg} \mathrm{m}^{-3}$. Zone B was located between La Palma and Tenerife islands and also contained cold-core eddies, but surface chlorophyll values were generally higher than in Zone A. Finally, all stations sampled in the eastern part of the archipelago were grouped in Zone C, characterised by cold surface waters and chlorophyll concentrations generally exceeding $0.02 \mathrm{mg} \mathrm{m}^{-3}$ (Fig. 3). These characteristics of the surface waters were indicative of differences in water-column properties between zones. Surface chlorophyll was significantly correlated with water-column integrated chlorophyll, either in the upper $100 \mathrm{~m}$ layer $(\mathrm{r}=0.605, \mathrm{n}=65$, $\mathrm{p}<0.01)$ or in the 0 to $150 \mathrm{~m}$ layer $(\mathrm{r}=$ $0.472, \mathrm{n}=65, \mathrm{p}<0.01$ ). Significant differences also existed in water-columnintegrated chl $a$ and PP values between zones (Table 1). Zones A and B had equivalent mean values of either chl a or PP for the upper $100 \mathrm{~m}$ layer, whereas zones $\mathrm{B}$ and $\mathrm{C}$ had nonsignificant differences in the values of either chl $a$ at the surface or integrated in the 0 to $150 \mathrm{~m}$ layer.

Vertical profiles of temperature and chl $a$, the latter estimated by conversion of the measurements of the CTD fluorometer, also showed differences between zones (Fig. 4). A well-mixed surface layer reaching to ca $40 \mathrm{~m}$ depth was well developed in the stations of Zone A, as evidenced by temperature profiles. A seasonal thermocline was marked at some stations (e.g. Stn 37) but was less so at others (e.g. Stn 1), indicating frequent mixing events in the upper $100 \mathrm{~m}$ at the latter stations. The variability in the temperature profiles of the stations in Zone A was also reflected by the differences in values measured at either the surface or $100 \mathrm{~m}$ depth of the end-member stations (e.g. Stns 1 \& 37). Deep chlorophyll maxima of similar magnitude developed at all stations in this zone between 60 and $100 \mathrm{~m}$ depth, and their position in the water-column was closer to the surface at stations with colder temperatures (Fig. 4). Temperature profiles for the stations of Zone B were more homogeneous than for Zone $A_{i}$ however, no clear signal of the seasonal thermocline was found, except for Stn 72, which
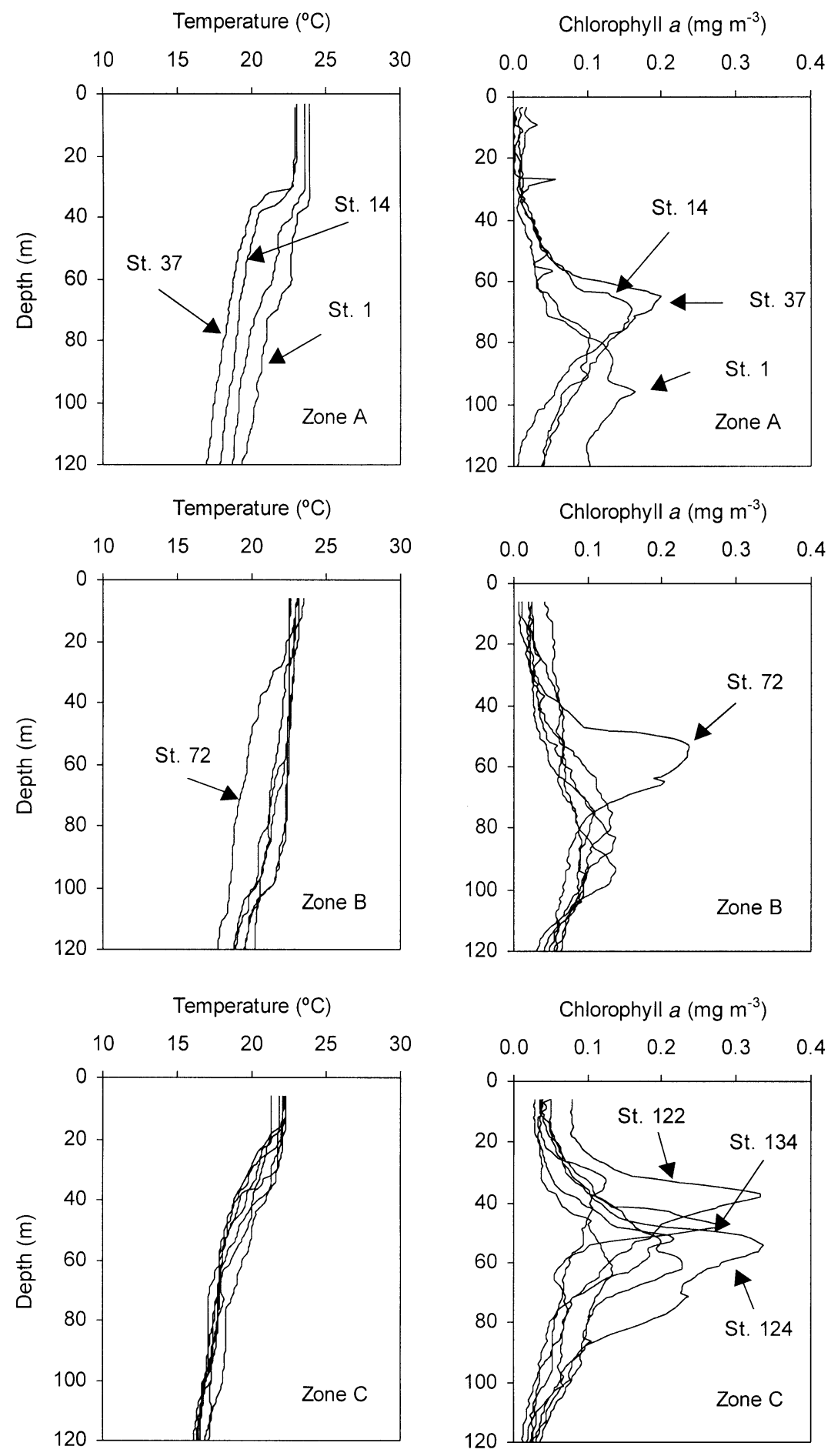

Fig. 4. Vertical profiles of temperature and chl a at stations where bacterial samples were collected grouped by characteristic oceanographic zones (see 'Results' for description) 
showed the lowest subsurface temperature values. As in Zone A, the largest and shallowest deep chlorophyll maximum was related to the coldest temperatures (Stn 72). In contrast, stations in Zone $\mathrm{C}$ showed less extreme variations in temperature profiles, being characterised by a shallow upper mixing layer and a subsurface layer with weak thermoclines. The deep chlorophyll maxima, located between 35 and $60 \mathrm{~m}$ depth, were well marked in this zone, reaching the maximum absolute values of all stations studied.

Despite the deep maximum concentration of chl a in all zones, primary production was generally higher at the surface (Zone A) or above the chlorophyll maximum (Fig. 5). The average depth of the production maximum was $50 \mathrm{~m}$ in Zone B and $25 \mathrm{~m}$ in Zone C. Mean maximum values were higher in Zone $\mathrm{C}$, where they almost doubled those of Zones A and B. Production rates measured below the deep chlorophyll maximum were $>0.2 \mathrm{mg} \mathrm{C} \mathrm{m}^{-3} \mathrm{~h}^{-1}$.

The dominant phytoplankton species determined in all zones were dinoflagellates, particularly small forms (Table 2), which attained densities of up to 73 cells $\mathrm{ml}^{-1}$. In contrast, diatoms rarely exceeded 1 cell ml $\mathrm{m}^{-1}$ in the samples studied, they reached maximum abundances in Zone C (9 cells $\left.\mathrm{ml}^{-1}\right)$. Abundance of large and mediumsized flagellates (8 to $10 \mu \mathrm{m}$ ) were generally $>5$ cells $\mathrm{ml}^{-1}$ throughout the area.

\section{Pelagic bacteria}

Coccoid cyanobacteria ranged from ca. 0.1 to $9.4 \times 10^{3}$ cells $\mathrm{ml}^{-1}$. Their vertical distribution displayed maximum values in subsurface layers: at 50 and $90 \mathrm{~m}$ in Zone $\mathrm{A}$, at $70 \mathrm{~m}$ in Zone B, and between 40 and $60 \mathrm{~m}$ in Zone $\mathrm{C}$ (Fig. 6). Abundance values of heterotrophic bacteria ranged from 1 to $5.9 \times$ $10^{5}$ cells $\mathrm{ml}^{-1}$ in the upper $100 \mathrm{~m}$, and mean abundance decreased with increasing depth. Zone $\mathrm{C}$ displayed higher mean values of $\mathrm{HB}$ in the upper $60 \mathrm{~m}$ compared to stations in other zones. Bacterial production (not measured in Zone A) showed similar vertical profiles to those of $\mathrm{HB}_{\text {; }}$ maximum values generally occurred at depth $(90 \mathrm{~m}$ in Zone $\mathrm{B}$ and between 60 and $80 \mathrm{~m}$ in Zone $\mathrm{C}$ ), although a
Fig. 5. Vertical profiles (means $\pm \mathrm{SE}$ ) of chl a concentration, measured from acetone extracts, and primary production (PP) in the selected oceanographic zones. Number of samples averaged for each depth is indicated 
Table 2. Mean $( \pm \mathrm{SD})$ abundance $\left(\right.$ cells $\left.\mathrm{ml}^{-1}\right)$ of the main phytoplankton species and groups in a total of 33 samples examined. $\%$ : percent of samples in which the species or group appeared. -: absent

\begin{tabular}{|c|c|c|c|c|c|c|c|}
\hline \multirow[t]{2}{*}{ Species or group } & \multirow[t]{2}{*}{$\%$} & \multicolumn{2}{|c|}{ Zone A } & \multicolumn{2}{|c|}{ Zone B } & \multicolumn{2}{|c|}{ Zone C } \\
\hline & & Mean & SD & Mean & $\mathrm{SD}$ & Mean & $\mathrm{SD}$ \\
\hline Dinophyceae & 91 & 3.1 & 11.4 & 2.3 & 7.8 & 3.8 & 20.6 \\
\hline Pronoctiluca acuta (Lohmann) Schiller & 15 & 0.3 & - & 0.1 & - & 0.2 & 0.0 \\
\hline Oxytoxum cf. longiceps Schiller & 21 & - & - & 0.2 & 0.1 & 0.4 & 0.1 \\
\hline Oxytoxum sp. & 21 & 0.6 & 0.1 & 0.8 & 0.6 & 1.5 & 0.7 \\
\hline Torodinium robustum Kofoid \& Swezy & 24 & 0.3 & 0.2 & 0.2 & 0.0 & 0.2 & 0.0 \\
\hline Gyrodinium glaucum (Lebour) Kofoid \& Swezy & 27 & 0.6 & 0.4 & 0.3 & 0.0 & 0.2 & 0.1 \\
\hline Oxytoxum gracile Schiller & 30 & 1.0 & 0.5 & 0.9 & 0.2 & 1.0 & 0.6 \\
\hline Cachonina hallii Freudentahl \& Lee & 45 & 4.3 & 3.1 & 2.8 & - & 4.1 & 3.4 \\
\hline Gyrodinium spirale (Bergh) Kofoid \& Swezy & 58 & 0.3 & 0.1 & 0.4 & 0.4 & 0.3 & 0.2 \\
\hline Dinoflagellates $>30 \mu \mathrm{m}$ & 73 & 0.3 & 0.2 & 0.4 & 0.1 & 0.3 & 0.1 \\
\hline Dinoflagellates $<30 \mu \mathrm{m}$ & 100 & 22.2 & 10.9 & 19.3 & 7.7 & 32.9 & 20.3 \\
\hline Other dinoflagellates & 100 & 1.0 & 1.0 & 0.5 & 0.7 & 0.6 & 0.8 \\
\hline Diatomophyceae & 100 & 0.4 & 0.7 & 0.3 & 0.4 & 0.7 & 1.8 \\
\hline Leptocylindrus danicus Cleve & 515 & 0.4 & - & - & - & 1.1 & 0.8 \\
\hline Rhizosolenia setigera Brightwell & 15 & - & - & - & - & 0.2 & 0.0 \\
\hline Pseudonitzschia subcurvata (Hasle) Fryxell & 18 & 0.2 & - & 0.2 & - & 0.3 & 0.2 \\
\hline Rhizosolenia fragilissima Bergon & 18 & 0.4 & - & - & - & 1.1 & 0.8 \\
\hline Pennate diatoms $<30 \mu \mathrm{m}$ & 21 & 0.4 & 0.3 & 0.4 & 0.2 & 0.2 & - \\
\hline Nitzschia longissima (Brébisson) Grunow & 24 & - & - & 0.2 & - & 0.8 & 0.9 \\
\hline Pennate diatoms $>30 \mu \mathrm{m}$ & 36 & 0.5 & 0.3 & 0.2 & 0.0 & 0.5 & 0.4 \\
\hline Pseudonitzschia sp. & 42 & 0.4 & 0.3 & 0.4 & 0.2 & 1.2 & 0.8 \\
\hline Other diatoms & 100 & 0.5 & 0.6 & 0.3 & 0.3 & 0.6 & 0.6 \\
\hline Cryptophyceae & 67 & 3.5 & 2.4 & 1.8 & 1.2 & 5.6 & 6.1 \\
\hline Other groups & 100 & 0.8 & 1.5 & 0.2 & 0.5 & 0.7 & 1.6 \\
\hline Unidentified flagellates $(8-10 \mu \mathrm{m})$ & 88 & 6.5 & 3.6 & 5.5 & 3.2 & 9.5 & 7.4 \\
\hline
\end{tabular}

secondary maximum also appeared at the surface (Fig. 6). However, it is difficult to determine a consistent pattern of variation with depth in our observations because of the small number of samples available for some depths.

No significant differences were found between mean values of either $\mathrm{CB}, \mathrm{HB}$ or PBact in each zone (Kruskal-Wallis test, $\mathrm{p}>0.05, \mathrm{n}=57$ for $\mathrm{CB}, \mathrm{n}=82$ for $\mathrm{HB}, \mathrm{n}=63$ for PBact). However, mean values of bacterial production normalized to bacterial abundance in Zones B $\left(12.9 \pm 12.1 \times 10^{-2}\right.$ amol leu cell ${ }^{-1} \mathrm{~h}^{-1}$, mean \pm $\mathrm{SD}, \mathrm{n}=37)$ and $\mathrm{C}\left(7.5 \pm 8.6 \times 10^{-2} \mathrm{amol} \mathrm{leu} \mathrm{cell}{ }^{-1} \mathrm{~h}^{-1}\right.$, mean $\pm \mathrm{SD}, \mathrm{n}=26$ ) were significantly different (MannWhitney $U$-test, $\mathrm{p}<0.01, \mathrm{n}=63$ ). Bacterial abundance decreased below $100 \mathrm{~m}$, with little variation down to $300 \mathrm{~m}$ (Fig. 7). Values were generally near $10^{5}$ cells $\mathrm{ml}^{-1}$, except for Stn 83, where concentrations near $3 \times$ $10^{5}$ were found between 100 and $300 \mathrm{~m}$. Bacterial production also decreased below $100 \mathrm{~m}$ at most of the studied stations. The exception was again Stn 83, in which production values increased from ca 10 pmol

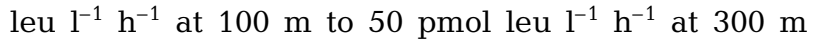
(Fig. 7).

Considering all observations, CB was significantly correlated to chl a $(\mathrm{r}=0.677, \mathrm{n}=64, \mathrm{p}<0.001)$ and to HB $(r=0.328, n=58, p<0.05)$ but not to temperature.
However, these correlations accounted for less than $50 \%$ of the variance of $\mathrm{CB}$. In contrast, HB was not significantly correlated to either chl $a$, Pbact or temperature. The mean depth of maximum values in the vertical profiles of bacterial and phytoplankton variables was related to water-column stratification (Fig. 8). All biological maxima considered were significantly above the seasonal pycnocline near $95 \mathrm{~m}$ (Table 3). Maximum values of $\mathrm{CB}$ appeared significantly below maximum $\mathrm{HB}$ and the limit of the upper mixing layer. The HB maximum occurred significantly above maximum chl a and the intermediate pycnocline. Other significant differences between the mean depth of maximum values displayed in Fig. 8 were those for chl $a$ and PP, the former occurring significantly below the upper mixing layer and maximum PP.

\section{Carbon budgets}

Leucine incorporation by bacteria was converted to carbon production using the empirical conversion factors measured at some stations (Table 4). The conversion factors computed by the procedure described in Kirchman \& Ducklow (1993) were not significantly different (Wilcoxon test, $\mathrm{p}>0.05, \mathrm{n}=5$ ) from those com- 
puted by the procedure of Bjørnsen \& Kuparinen (1991). Leucine-to-carbon conversion factors computed for stations in Zone B were significantly higher than those for stations in Zone $\mathrm{C}$ (Wilcoxon test, $\mathrm{p}$ >
$0.05, \mathrm{n}=5$ ); therefore, the mean value of the carbon conversion factor estimated by the method of Bjørnsen \& Kuparinen (1991) for each zone was employed to obtain bacterial carbon production estimates.
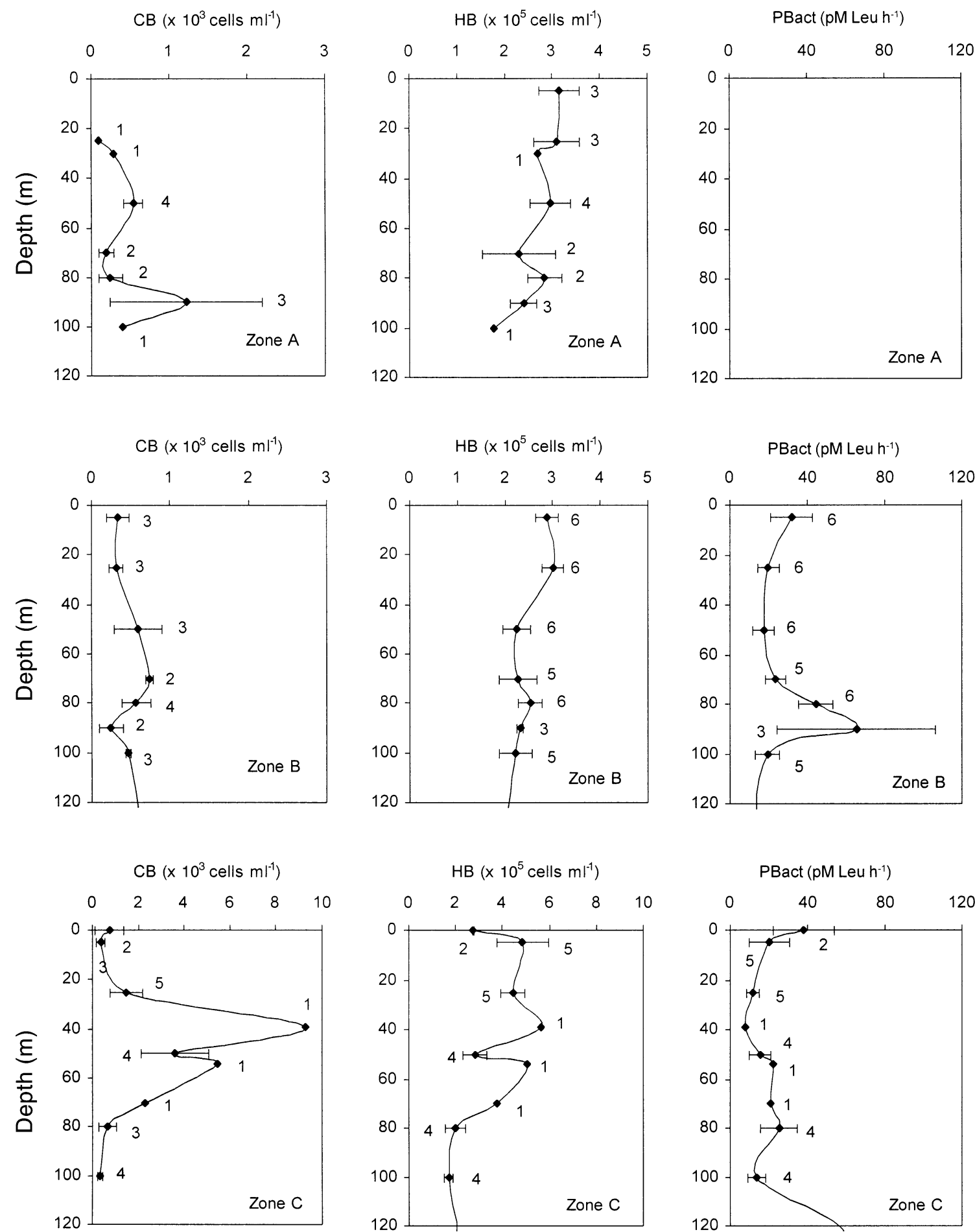

Fig. 6. Vertical profiles (means $\pm \mathrm{SE}$ ) of abundance of cyanobacteria $(\mathrm{CB})$ and heterotrophic bacteria (HB), and of leucine incorporation (PBact, pM leu) in the upper $100 \mathrm{~m}$ of the selected oceanographic zones. Number of samples averaged for each depth is indicated. PBact was not determined in Zone A 

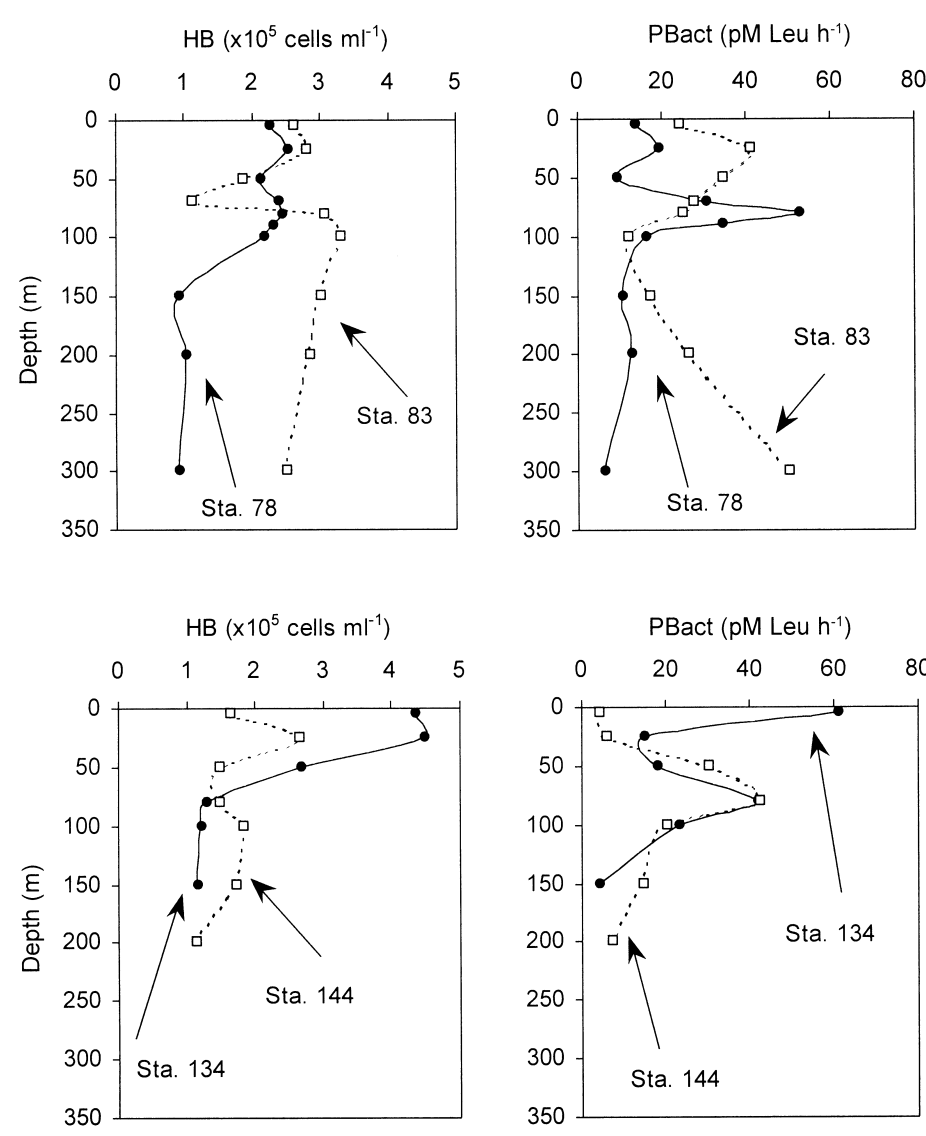

Fig. 7. Examples of vertical distribution of heterotrophic bacteria (HB) and leucine incorporation (PBact, pM leu) between the surface and $300 \mathrm{~m}$ depth at selected stations

Water-column integrated bacterial biomass ranged from 291 to $731 \mathrm{mg} \mathrm{C} \mathrm{m}^{-2}$ (Table 5). No significant differences between mean values of integrated bacterial biomass for each zone were found (Kruskal-Wallis test, $\mathrm{p}>0.05, \mathrm{n}=15$ ), but maximum and minimum values occurred in stations of Zone C. Integrated bacterial carbon production varied between 0.6 and $12 \mathrm{mg} \mathrm{C}$

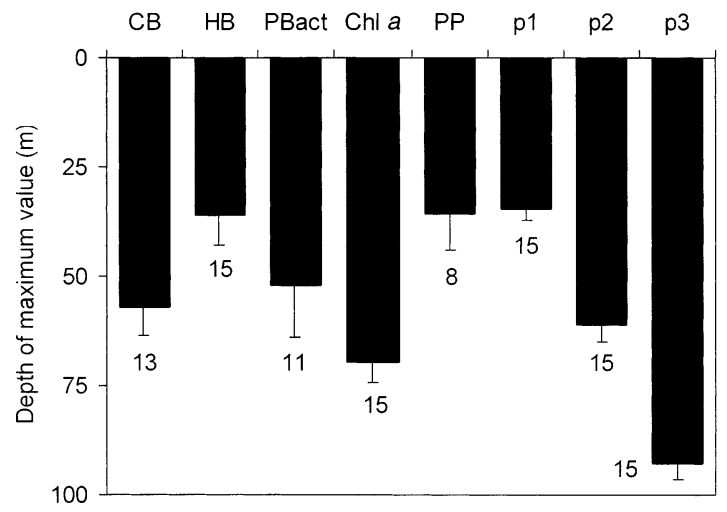

Fig. 8. Mean depth $( \pm \mathrm{SE})$ of the maximum value of bacterial, phytoplankton and water-column stratification variables (see 'Results') in the 0 to $100 \mathrm{~m}$ layer. p1, p2 and p3: depths of surface upper mixing layers (see 'Materials and methods'). Number of samples averaged is indicated below each bar

$\mathrm{m}^{-2} \mathrm{~h}^{-1}$ (15 and $289 \mathrm{mg} \mathrm{C} \mathrm{m} \mathrm{m}^{-2} \mathrm{~d}^{-1}$ ). In this case, mean values of bacterial production in Zones $\mathrm{B}$ and $\mathrm{C}$ were significantly different (Mann-Whitney $U$-test, $\mathrm{p}<0.01$, $\mathrm{n}=11$ ). Bacterial growth rates, estimated from integrated values of carbon production and biomass, ranged from 0.028 to $0.437 \mathrm{~d}^{-1}$ and corresponded to generation times from ca 2 to more than $25 \mathrm{~d}$, with the largest range of values in Zone $\mathrm{C}$. Growth rates in Zone B were significantly higher (and generation times lower) than those in Zone C (Mann-Whitney $U$-test, p < $0.01, \mathrm{n}=11$ ).

Using stations where simultaneous measurements of bacterial and phytoplankton variables were made, we computed daily carbon budgets in the upper $100 \mathrm{~m}$ for Zones B and C (Table 6). Despite equivalent biomass values of bacteria or phytoplankton in both zones, the mean primary production of Zone $\mathrm{C}$ was more than twice the value computed for Zone B, while mean bacterial production was only slightly higher in the latter zone. Bacterial biomass exceeded phytoplankton bio-

Table 3. Probability of significance of paired comparisons (Wilcoxon test) between depth of maximum value of selected bacterial and environmental variables. Upper half of the matrix shows probability of significance $\left({ }^{*} \mathrm{p}<0.05,{ }^{* *} \mathrm{p}<0.01,{ }^{* * *} \mathrm{p}<0.001, \mathrm{~ns}\right.$ : not significant), lower half of the matrix shows number of data pairs compared. Variable names are explained in Methods. CB: cyanobacteria; HB heterotrophic bacteria; PBact: production of heterotrophic bacteria; PP: primary production; p1-p3: depths of surface upper mixing layers

\begin{tabular}{|c|c|c|c|c|c|c|c|c|}
\hline & CB & HB & PBact & Chl a & PP & $\mathrm{p} 1$ & $\mathrm{p} 2$ & p3 \\
\hline CB & - & ${ }^{*}$ & $\mathrm{~ns}$ & ns & ${ }^{*}$ & ${ }^{*}$ & ns & ${ }^{* *}$ \\
\hline HB & 13 & - & ns & $* *$ & ns & ns & $*$ & $* *$ \\
\hline PBact & 9 & 11 & - & ns & ns & ns & $\mathrm{ns}$ & $* *$ \\
\hline Chl a & 13 & 15 & 11 & - & ${ }^{*}$ & ${ }^{* *}$ & ns & ${ }^{* *}$ \\
\hline $\mathrm{PP}$ & 8 & 8 & 6 & 8 & - & ns & $*$ & $*$ \\
\hline p1 & 13 & 15 & 11 & 15 & 8 & - & $* * *$ & $* * *$ \\
\hline p2 & 13 & 15 & 11 & 15 & 8 & 15 & - & $* * *$ \\
\hline p3 & 13 & 15 & 11 & 15 & 8 & 15 & 15 & - \\
\hline
\end{tabular}


Table 4. Empirical conversion factors between leucine and cell growth or carbon uptake. FCell $\mathrm{KD}_{\mathrm{KD}}$ leucine to cell conversion factor $\left(\times 10^{17}\right.$ cells $\left.[\mathrm{mol} \mathrm{leu}]^{-1}\right) \mathrm{com}-$ puted by procedure of Kirchman \& Ducklow (1993); FCell ${ }_{\mathrm{BK}}$ : leucine to cell conversion factor $\left(\times 10^{17}\right.$ cells $\left.[\mathrm{mol} \mathrm{leu}]^{-1}\right)$ computed by procedure of Bjørnsen \& Kuparinen (1991); $\mathrm{FC}_{\mathrm{KD}}$ : leucine to carbon conversion factor $\left(\mathrm{kg} \mathrm{C}[\mathrm{mol} \mathrm{leu}]^{-1}\right.$ ) computed by procedure of Kirchman \& Ducklow (1993). $\mathrm{FC}_{\mathrm{BK}}$ : leucine to carbon conversion factor $\left(\mathrm{kg} \mathrm{C}[\mathrm{mol} \mathrm{leu}]^{-1}\right.$ ) computed by procedure of Bjørnsen \& Kuparinen (1991). Cell to carbon conversion was made using the estimated empirical factor of $17 \mathrm{fg} \mathrm{C} \mathrm{cell}^{-1}$ (see 'Materials and methods')

\begin{tabular}{|lcccc|}
\hline Station & FCell $_{\mathrm{KD}}$ & FCell $_{\mathrm{BK}}$ & $\mathrm{FC}_{\mathrm{KD}}$ & $\mathrm{FC}_{\mathrm{BK}}$ \\
\hline Zone B & & & & \\
65 & 1.83 & 1.26 & 3.11 & 2.14 \\
91 & 2.51 & 2.25 & 4.27 & 3.83 \\
Mean (SD & $2.17(0.48)$ & $1.76(0.70)$ & $3.69(0.82)$ & $2.98(1.20)$ \\
Zone C & & & & \\
107 & 0.74 & 0.96 & 1.26 & 1.63 \\
115 & 0.39 & 0.71 & 0.66 & 1.21 \\
134 & 0.21 & 0.55 & 0.36 & 0.41 \\
Mean (SD) & $0.45(0.27)$ & $0.74(0.21)$ & $0.76(0.45)$ & $1.08(0.61)$ \\
Total & & & & \\
Mean (SD) & $1.14(0.99)$ & $1.15(0.67)$ & $1.93(1.69)$ & $1.84(1.28)$ \\
\hline
\end{tabular}

mass in all cases by approximately $30 \%$. In contrast, bacterial production was equivalent to a small fraction of both phytoplankton biomass or production, except at Stn 65, where both production rates were nearly equivalent. Stations in Zone $\mathrm{C}$ showed the lowest ratios of bacterial production relative to either phytoplankton biomass or production in the upper surface layer.

\section{DISCUSSION}

Mesoscale eddies are a major characteristic of the upper waters in the Canary region and greatly influence plankton distribution and productivity (Arístegui et al. 1994, 1997). The oceanographic situation found during the BIOCAN-98 cruise can be considered typical of late summer in this region, characterized by coexisting coldand warm-core eddies and the marked influence of the NW African upwelling in the eastern islands of the archipelago. Cold-core cyclonic eddies generally have surface waters with low chlorophyll inside the eddy, while relatively high chlorophyll concentrations can be found at the surface near the eddy limits. Local upwelling may enhance phytoplankton productivity in subsurface layers near the center of the eddy and at its borders (Arístegui et al. 1997). Warm-core anticyclonic eddies were usually associated with relatively high chlorophyll concentrations inside the eddy, probably due to transport and concentration of phytoplankton patches. Trade winds, which interact with island topography and the Canary current in driving and maintaining these eddies (Arístegui et al. 1994, 1997), reach their maximum intensity during the summer months, resulting in maximum development of the NW African upwelling. Our observations of relatively cold and phytoplankton-rich surface waters in the eastern part of the archipelago (Zone C), along with greatly modified thermoclines and shallower subsurface chlorophyll maxima, confirm the importance of the upwelling in this region. In contrast, the productivity of the relatively low-phytoplankton waters in the western islands (Zones A and B) may depend to a large extent on local enrichments caused by eddy-induced up-

Table 5. Integrated biomass and production values of heterotrophic bacteria in a $100 \mathrm{~m}$ deep water-column. Cell abundances were converted to carbon biomass $\left(\mathrm{HB}_{\mathrm{C}}, \mathrm{mg} \mathrm{C} \mathrm{m}{ }^{-2}\right.$ ) using the factor: $17 \mathrm{fg} \mathrm{C} \mathrm{cell}^{-1}$ (see 'Materials and methods'). Bacterial leucine incorporation was converted to carbon uptake ( Pbact $_{\mathrm{C}}$, mg C $\mathrm{m}^{-2} \mathrm{~h}^{-1}$ ) using the average empirical factor determined for each zone (Table 4). Daily bacterial production (Pbact ${ }_{C}^{d}, \mathrm{mg} \mathrm{C} \mathrm{m}^{-2} \mathrm{~d}^{-1}$ ) was computed by multiplying hourly values by 24 . Bacterial growth rate $\left(\mu, d^{-1}\right)$ was computed as $\ln (1+$ $\mathrm{Pbact}_{\mathrm{C}}^{\mathrm{d}} / \mathrm{HB}_{\mathrm{C}}$ ). Generation time of the bacterial population (GT, days) was computed as $\ln 2 / \mu$. -: no data

\begin{tabular}{|lccccc|}
\hline Station & $\mathrm{HB}_{\mathrm{C}}$ & Pbact $_{\mathrm{C}}$ & Pbact $_{\mathrm{C}}^{\mathrm{d}}$ & $\mu$ & $\mathrm{GT}$ \\
\hline Zone A & & & & & \\
1 & 391.4 & - & - & - & - \\
7 & 442.9 & - & - & - & - \\
14 & 489.5 & - & - & - & - \\
37 & 507.6 & - & - & - & - \\
Mean (SD) & $457.8(52.0)$ & $-(-)$ & $-(-)$ & $-(-)$ & $-(-)$ \\
Zone B & & & & & \\
65 & 526.7 & 12.0 & 289.0 & 0.437 & 1.6 \\
72 & 357.6 & 8.0 & 192.7 & 0.431 & 1.6 \\
78 & 374.8 & 6.5 & 155.6 & 0.347 & 2.0 \\
83 & 383.8 & 8.5 & 203.8 & 0.426 & 1.6 \\
91 & 381.5 & 5.2 & 126.0 & 0.285 & 2.4 \\
97 & 445.8 & 7.4 & 177.9 & 0.336 & 2.1 \\
Mean (SD) & $441.7(63.8)$ & $8.0(2.3)$ & $190.8(55.5)$ & $0.377(0.063)$ & $1.9(0.3)$ \\
Zone C & & & & & \\
122 & 705.7 & 1.3 & 32.2 & 0.045 & 15.5 \\
124 & 730.5 & 2.0 & 48.3 & 0.064 & 10.8 \\
134 & 444.0 & 2.7 & 64.5 & 0.136 & 5.1 \\
137 & 527.1 & 0.6 & 14.8 & 0.028 & 25.1 \\
144 & 290.6 & 2.4 & 57.7 & 0.181 & 3.8 \\
Mean (SD) & $539.6(183.9)$ & $1.8(0.8)$ & $43.5(20.1)$ & $0.091(0.065)$ & $12.1(8.6)$ \\
& & \multicolumn{3}{c}{} & \\
\hline
\end{tabular}




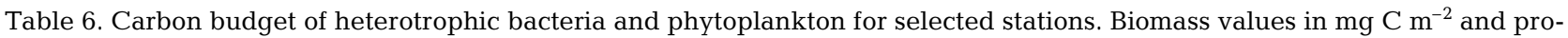
duction in $\mathrm{mg} \mathrm{C} \mathrm{m}^{-2} \mathrm{~d}^{-1}$. Bacterial biomass $\left(\mathrm{HB}_{\mathrm{C}}\right)$ and production (Pbact ${ }_{\mathrm{C}}^{\mathrm{d}}$ ) as in Table $5, \mathrm{P}_{\mathrm{C}}$ : phytoplankton carbon computed from chl a using the conversion $50 \mathrm{~g} \mathrm{C}(\mathrm{g} \mathrm{chl} a)^{-1}$. $\mathrm{PP}^{\mathrm{d}}$ : daily primary production computed for a $12 \mathrm{~h}$ light period. Percent ratios of bacterial biomass and production relative to phytoplankton are also given

\begin{tabular}{|c|c|c|c|c|c|c|c|}
\hline Station & $\mathrm{HB}_{\mathrm{C}}$ & Pbact ${ }_{C}^{d}$ & $\mathrm{P}_{\mathrm{C}}$ & $\mathrm{PP}^{\mathrm{d}}$ & $\% \mathrm{HB}_{\mathrm{C}}: \mathrm{P}_{\mathrm{C}}$ & $\%$ Pbact ${ }_{C}^{d}: P_{C}$ & $\%$ Pbact ${ }_{C}^{d}: P^{d}$ \\
\hline \multicolumn{8}{|l|}{ Zone B } \\
\hline 65 & 526.7 & 289.0 & 440.0 & 172.8 & 120 & 66 & 167 \\
\hline 78 & 374.8 & 155.6 & 245.0 & 243.6 & 153 & 64 & 64 \\
\hline Mean (SD) & $450.8(107.4)$ & $222.3(94.3)$ & 342.5 (137.9) & $208.2(50.1)$ & $136(24)$ & $65(2)$ & $116(73)$ \\
\hline \multicolumn{8}{|l|}{ Zone C } \\
\hline 124 & 730.5 & 48.3 & 495.0 & 603.6 & 148 & 10 & 8 \\
\hline 144 & 290.6 & 57.7 & 280.0 & 432.0 & 104 & 21 & 13 \\
\hline Mean (SD) & $510.6(311.1)$ & $53.0(6.6)$ & $387.5(152.0)$ & $517.8(121.3)$ & $126(31)$ & $15(8)$ & $11(4)$ \\
\hline
\end{tabular}

welling, as suggested by the association between larger subsurface chlorophyll maxima and shallower and eroded thermoclines at some stations. The significantly higher water-column-integrated (0 to $150 \mathrm{~m}$ ) chlorophyll concentration of stations in Zone B compared to Zone A may be a consequence of the presence of islands that favour eddy develoment and plankton transport from the coast (Arístegui et al. 1989, 1994, 1997). Phytoplankton species composition reflects the general oligotrophy of these waters. Small dinoflagellates were always the most abundant cells for the 5 to $30 \mu \mathrm{m}$ phytoplankton size group, but total phytoplankton abundance was generally lower than 50 cells $\mathrm{ml}^{-1}$. However, the influence of the African upwelling was indicated by the greater species diversity and an increase in the abundance of diatoms in Zone C compared to the other zones.

Our results of bacterial abundance agree with those of Ballesteros (1994) for the Canary Islands region in June 1990, and they are also within the range reported for other studies in oligotrophic oceanic waters (Campbell et al. 1994, Ducklow et al. 1995, Pomeroy et al. 1995, Binder et al. 1996, Carlson et al. 1996). The maximum values observed in this study are lower than those observed in oceanic stations of oligotrophic waters near the Iberian peninsula, either in the NW Mediterranean $\left(1.6 \times 10^{6}\right.$ cells ml $^{-1}$; Gasol et al. 1998) or in the S Bay of Biscay, in the NE Atlantic $\left(1.9 \times 10^{6}\right.$ cells $\mathrm{ml}^{-1}$; Barquero et al. 1998). Similarly, our measured abundances of coccoid cyanobacteria are within the range of reported values in oceanic waters (McManus \& Dawson 1994, Li 1995, Binder et al. 1996) and in the Canary Islands (Ballesteros 1994). Recent studies of pico- and nanoplankton in oceanic waters using flow cytometry report large abundances of prochlorophytes (Campbell et al. 1994, Li 1995, Binder et al. 1996, Zubkov et al. 1998) that may be difficult to distinguish from small heterotrophic bacteria using epifluorescence microscopy (Sieracki et al. 1995), thus overestimating bacterial numbers and underestimat- ing primary producers. However, Campell et al. (1994) and Binder et al. (1996) report that prochlorophyte abundance was $<45 \%$ of the abundance of heterotrophic bacteria in the vicinity of the subsurface chlorophyll maximum, and $<5 \%$ in the surface. In the same way, Li (1995) concluded that, even when prochlorophytes comprised on average $78 \%$ of the cell numbers of ultraphytoplankton $(<5 \mu \mathrm{m}$ in size) in the central Atlantic (including samples from the Canary region), their contribution did not exceed $10 \%$ of carbon biomass, and $20 \%$ of primary production. More recently, Buck et al. (1996) and Zubkov et al. (1998) found that the biomass of heterotrophic bacteria was $>50 \%$ of total picoplankton biomass in the subtropical north Atlantic. In our study, the relatively low abundances of heterotrophic bacteria compared to similar studies in oceanic waters, and the absence of a significant correlation between bacterial abundance and chlorophyll, suggests that prochlorophytes did not greatly affect our estimations.

Estimations of bacterial carbon biomass in oligotrophic environments are largely dependent on the conversion factors between abundance, cell biovolume and carbon employed. We computed a mean carbon content of $17 \mathrm{fg} \mathrm{C} \mathrm{Cell}^{-1}$ that is close to the $20 \mathrm{fg} \mathrm{C} \mathrm{cell}^{-1}$ (Simon \& Azam 1989) used in other oceanic studies (eg. Ducklow 1993: Li et al. 1993) and included in the range determined for marine bacteria (5.9 to $23.5 \mathrm{fg} \mathrm{C}$ cell $^{-1}$; Fukuda et al. 1998). Although our estimates of bacterial size by visual observation under the microscope were higher when compared with other studies in which bacteria were measured with more precise techniques (Carlson et al. 1996, Gasol et al. 1998), our computations of bacterial biomass yielded an average value of ca $10 \mathrm{mg} \mathrm{C} \mathrm{m}^{-2}$ in the upper mixing layer, within the range reported for some studies (Campbell et al. 1994, Barquero et al. 1998), but relatively high compared to values reported for others (Pomeroy et al. 1995, Carlson et al. 1996). Nevertheless, minimum values in our study were lower than those reported for the 
nearby African upwelling (Head et al. 1996) and than those observed during phytoplankton blooms in oceanic regions (Ducklow et al. 1993, Li et al. 1993). The same is true for the computed bacterial carbon production values. The large range of values reported for oligotrophic regions: 0.2 to $>30 \mathrm{mg} \mathrm{C} \mathrm{m}^{-2} \mathrm{~d}^{-1}$ (Ducklow 1993, Pomeroy et al. 1995, Carlson et al. 1996, Jones et al. 1996, Gasol et al. 1998) includes our values, which are low compared to those of productive regions (Ducklow et al. 1993, Li et al. 1993, Head et al. 1996). In addition to these comparisons, there are several methodological considerations that support the reliability of our results on bacterial biomass and production in Canarian waters.

First, we used additions of leucine which were relatively high compared to the 10 to $50 \mathrm{nmol} \mathrm{l}^{-1}$ used in other studies (Simon \& Azam 1989, Li et al. 1993, Carlson et al. 1996, Gasol et al. 1998). Large additions of leucine ensure that bacteria use mainly the labelled amino acid in protein synthesis and not unlabelled extra- or intracellular pools of leucine (Simon \& Azam 1989), since the goal is to obtain rates of protein synthesis and not amino acid turnover at in situ concentrations (Kirchman 1993). Preliminary experiments with bacteria from coastal and oceanic stations in the upwelling area of NW Spain showed that leucine incorporation reached complete saturation at concentrations ranging from 42 to $>100 \mathrm{nM}$ even in oligotrophic stations (A. Bode, A. Cid \& J. Valencia, unpubl. results). Using these data, the estimated effect of additions of leucine of up to $150 \mathrm{nM}$ would have multiplied the incorporation rates expected at $50 \mathrm{nM}$ by 1.2 to 2.1 times (mean $1.7, \mathrm{n}=8$ ). However, in the absence of specific experiments to measure the saturation of leucine incorporation by bacteria of Canarian waters it is difficult to demonstrate a stimulating effect of the leucine additions employed. Comparison between our measured rates and those in the literature suggests that in our study leucine incorporation was not enhanced because of large initial additions.

Second, although our incubations were not made at in situ temperatures, we can discount any significant effect of temperature on the estimated bacterial production rates since other studies in temperate waters during summer have found no significant correlations between these 2 variables (Shiah \& Ducklow 1994), with other factors such as the availability of dissolved organic substrates probably controlling bacterial production. Similarly, the average conversion factor between leucine and carbon uptake determined in our study is within the range of empirical factors employed in other studies (Kirchman 1992, Li et al. 1993, Carlson et al. 1996) and is lower than the maximum theoretical value of $3.1 \mathrm{~kg} \mathrm{C}$ (mol leucine) ${ }^{-1}$, assuming that incorporated leucine is diluted by a factor of 2 in the intra- cellular pool (Kirchman 1993). Our estimates of hourly bacterial carbon-production rates can be considered as potential rates, but at the same time our results are within the published ranges of bacterial production and agree with the measured microbial respiration in Canarian waters (Aristegui \& Montero 1995) (see later discussion on carbon budgets).

Finally, there are reports of diurnal changes in leucine incorporation in oligotrophic environments (e.g. Gasol et al. 1998), with maximum rates occurring around noon. These changes are related to variations in dissolved organic carbon concentrations and imply a close coupling between bacterial activity and substrate availability in surface waters. Extrapolation of shortterm rates measured around noon to daily incorporation may be overestimated if significant changes in short-term rates occur during the day. In our study, all incubation experiments were made around noon and dissolved organic carbon was not measured. However, we can estimate the potential effect of daily changes in bacterial production rates similar to those reported by Gasol et al. (1998), assuming that the value of hourly production at noon is $220 \%$ of daily mean rate and that rates decay to $80 \%$ of this mean value in an interval of $6 \mathrm{~h}$ around noon. In such case, our daily values of bacterial carbon production assuming constant rates would have overestimated actual values by up to $40 \%$; however, comparisons of our results with literature values and primary production rates (see below) do not suggest severe overestimations.

The abundance of heterotrophic bacteria was not significantly correlated to either temperature or chlorophyll concentration in our study. However, significant correlations between these variables were found at seasonal scales and during comparisons across systems (Cole et al. 1988, White et al. 1991, Shiah \& Ducklow 1994). Maximum abundance of heterotrophic bacteria was not directly related to phytoplankton vertical distribution in our samples. The observed distributions generally showed higher abundance of bacteria near the surface, but sometimes also near the subsurface chlorophyll maximum, the latter associated with the seasonal pycnocline displaying a typical subtropical structure' (sensu Cullen 1982). This subsurface chlorophyll maximum was repeatedly reported in Canarian waters (de León \& Braun 1973, Braun 1980, Real et al. 1981, Braun \& Real 1984, 1986, Arístegui et al. 1989, 1997, Fernández de Puelles \& Braun 1989, Arístegui 1990, Ojeda 1996). In contrast, maximum cyanobacterial abundances were related to the chlorophyll maximum, as in other studies of oceanic waters ( $\mathrm{Li}$ et al. 1993, McManus \& Dawson 1994, Binder et al. 1996). Surface maximum abundances of heterotrophic bacteria have been reported in most studies (Li et al. 1993, Binder et al. 1996, Carlson et al. 1996, Jones et al. 
1996). Indeed, some studies (e.g. Ducklow 1993) also noted the presence of relative maxima in the vertical distribution of bacteria near the surface and near the chlorophyll maximum, as in our study. The maximum near the surface occurred at depths equivalent to those of the highest rates of PP and PBact, which were located significantly above the chlorophyll maximum. It can be hypothesized that bacteria in the subsurface maximum efficiently utilize released organic matter from recent photosynthates and produce noticeable increases in their population numbers.

The integrated biomass and production rates of heterotrophic bacteria suggest that these organisms are important components of the carbon flux of the Canary region. The estimated growth rates and generation times indicate that bacteria were growing relatively fast compared to other oligotrophic regions (e.g. Carlson et al. 1996). The slower growth rates in Zone $\mathrm{C}$ were an additional indication of the influence of the African upwelling, as specific bacterial activity is generally reduced near active upwelling areas (Watson 1978, Hanson et al. 1986, Tenore et al. 1995, Barquero et al. 1998). Direct comparison of bacteria and phytoplankton at the same stations (Table 6) indicates that bacterial biomass exceeded phytoplankton carbon in the upper $100 \mathrm{~m}$, while bacterial production comprised from 10 to $66 \%$ of primary production. These values may be considered low compared to the average value of $190 \%$ reported by Ballesteros (1994) in waters around the Canary Islands in June 1990, but are within the range of 18 to $130 \%$ reported by Carlson et al. (1996) in the oligotrophic Sargasso Sea. Cyanobacteria would be comparatively less important, since their biomass would be less than half the estimated biomass of heterotrophic bacteria and less than $20 \%$ of phytoplankton carbon, assuming a cyanobacterial carbon content of $250 \mathrm{fg} \mathrm{C} \mathrm{cell}^{-1}$ (Campbell et al. 1994). Ballesteros (1994) estimated that cyanobacteria contributed up to $32 \%$ of phytoplankton carbon biomass in Canarian waters during spring but only $12 \%$ during summer. In contrast, bacterial production constituted a very variable fraction of particulate primary production in the upper mixing layer (from 14 to $108 \%$, according to values in Table 6), while literature values ranged from 2 to $92 \%$ in both oligotrophic (Ducklow 1993, Carlson et al. 1996, Jones et al. 1996) and eutrophic (Li et al. 1993, Head et al. 1996) ocean areas. Taking into account that the excretion of recent photosynthates by phytoplankton can account for up to $10 \%$ of particulate primary production (e.g. Wood et al. 1992), the ratio between bacterial and primary production could be reduced by ca $10 \%$. However, the existence of a close coupling between heterotrophic bacteria and phytoplankton may not require high ratios of bacterial to primary production. High bacterial growth rates can be sustained by phytoplankton populations growing faster than bacteria. Using the results in Table 6, we estimated phytoplankton growth rates of between 0.331 and $0.933 \mathrm{~d}^{-1}$, i.e. from 0.8 to 12.5 times the bacterial growth rates at the same stations. This suggests that primary production was high enough to support bacteria in the upper mixing layer even when the biomass of the latter generally exceeded phytoplankton biomass.

Gasol et al. (1998) compared leucine incorporation rates of bacteria in oligotrophic waters of the Western Mediterranean with daily changes in the concentration of dissolved organic carbon and concluded that the bacterial production of protein did not account for the observed disappearance of organic dissolved carbon. Low carbon conversion efficiencies, implying high bacterial respiration rates, may explain the use of relatively large amounts of dissolved substrates and increase the participation of bacteria in the carbon fluxes in oligotrophic marine areas (del Giorgio et al. 1997, Duarte \& Agustí 1998). We can examine further the implications of the measured bacterial biomass and production values in the pelagic ecosystem around the Canary Islands using the available information on biomass and carbon fluxes in this region (Table 7). Bacterial biomass and production were on average $24 \%$ of phytoplankton biomass or primary production per volume. Taking into account that phytoplankton were restricted mostly to the upper $100 \mathrm{~m}$ and that bacteria are distributed throughout the whole water column with no clear reduction in abundance or production, at least in the upper $300 \mathrm{~m}$, the integrated values suggest that bacterial production would account for ca $50 \%$ of primary production in the upper $200 \mathrm{~m}$. Even considering a reduction of bacterial production values below $100 \mathrm{~m}$ to $10 \%$ of the average values in the upper $100 \mathrm{~m}$, and an increase of $10 \%$ in primary production values to account for the excretion of recent photosynthates, integrated bacterial production would be still more than $50 \%$ of primary production in the upper $500 \mathrm{~m}$. Also, bacterial biomass and production exceeded the average values of micro- or mesozooplankton biomass and carbon ingestion, even when considering values integrated in a $500 \mathrm{~m}$ depth water column, thus indicating that bacteria are the main contributors to heterotrophic carbon in these waters. The values obtained in these comparisons do not vary greatly, even when one recalculates bacterial production at $50 \mathrm{nM}$ of leucine by dividing bacterial production by the empirical factor of 1.7 as discussed earlier. Reported carbon conversion efficiencies for aquatic bacteria ranged from $<10$ to $>50 \%$ of consumed carbon (Carlson \& Ducklow 1996, del Giorgio et al. 1997, Gasol et al. 1998). According to these values and those in Table 7 , bacteria in the euphotic zone (0 to $200 \mathrm{~m}$ ) 
Table 7. Preliminary carbon budget of the pelagic ecosystem in Canarian waters. Phytoplankton and bacterial biomass and production are averages for the upper $200 \mathrm{~m}$ of the water-column. Microzooplankton (100 to $250 \mu \mathrm{m}$ ) and mesozooplankton $(>200 \mu \mathrm{m})$ values are averages for the 0 to $200 \mathrm{~m}$ and 0 to $500 \mathrm{~m}$ layers, respectively. Microplankton respiration includes organisms smaller than $225 \mu \mathrm{m}$, i.e. mostly phytoplankton, bacteria and microheterotrophs. Biomass values in $\mathrm{mg} \mathrm{C} \mathrm{m}^{-3}$ and fluxes in $\mathrm{mg} \mathrm{C} \mathrm{m} \mathrm{m}^{-3} \mathrm{~d}^{-1}$

\begin{tabular}{|c|c|c|c|}
\hline Component & Mean \pm SD & Observations & Source \\
\hline Phytoplankton biomass ${ }^{a}$ & $11.4 \pm 19.0$ & All periods, all islands, $(n=362)$ & $\begin{array}{l}\text { Arístegui (1990) } \\
\text { Arístegui et al. (1989, 1997) } \\
\text { Fernández de Puelles \& Braun }(1989,1996) \\
\text { Ojeda (1996) }\end{array}$ \\
\hline Primary production & $4.2 \pm 5.8$ & $\begin{array}{l}\text { All periods, Gran Canaria and } \\
\text { Tenerife islands, }(\mathrm{n}=37)\end{array}$ & $\begin{array}{l}\text { de León \& Braun (1973) } \\
\text { Braun (1980) } \\
\text { Arístegui et al. (1989) } \\
\text { Fernández de Puelles \& Braun }(1989,1996)\end{array}$ \\
\hline Microzooplankton biomass ${ }^{\mathrm{b}}$ & $2.7 \pm 0.2$ & $\begin{array}{l}\text { All periods, Tenerife } \\
\text { Island, }(\mathrm{n}=25)\end{array}$ & $\begin{array}{l}\text { Fernández de Puelles (1987) } \\
\text { Fernández de Puelles \& Braun (1996) }\end{array}$ \\
\hline Mesozooplankton biomass ${ }^{\mathrm{b}}$ & $1.3 \pm 0.8$ & $\begin{array}{l}\text { All periods, Gran Canaria and } \\
\text { Tenerife islands, }(\mathrm{n}=33)\end{array}$ & $\begin{array}{l}\text { Hernández-León et al. (1984) } \\
\text { Fernández de Puelles (1987) } \\
\text { Fernández de Puelles \& Braun (1996) }\end{array}$ \\
\hline Microzooplankton ingestion ${ }^{\mathrm{c}}$ & 0.4 & All periods, Tenerife island & Fernández de Puelles \& Braun (1996) \\
\hline Mesozooplankton ingestion ${ }^{\mathrm{d}}$ & 0.4 & All periods, Tenerife island & $\begin{array}{l}\text { Braun (1981) } \\
\text { Fernández de Puelles \& Braun (1996) }\end{array}$ \\
\hline Microplankton respiration ${ }^{\mathrm{e}}$ & $17.7 \pm 6.6$ & Canarian waters, $(\mathrm{n}=14)$ & Arístegui \& Montero (1995) \\
\hline Mesozooplankton respiration ${ }^{\mathrm{f}}$ & $0.1 \pm 0.1$ & All periods, Tenerife island, $(\mathrm{n}=26)$ & Hernández-León (1986) \\
\hline Bacterial biomass & $4.8 \pm 2.0$ & Summer, all islands, $(\mathrm{n}=15)$ & This study \\
\hline Bacterial production & $1.2 \pm 0.9$ & Summer, all islands, $(n=11)$ & This study \\
\hline \multicolumn{4}{|c|}{$\begin{array}{l}{ }^{b} \text { Carbon biomass }(\mathrm{C}) \text { computed from dry weight }(\mathrm{DW}) \text { using equation of Wiebe }(1988): \log (\mathrm{DW})=0.499+0.991 \log (\mathrm{C}) \\
{ }^{c} \text { Estimated annual average } \\
{ }^{\mathrm{d}} \text { Mean of reported annual average values: } 0.3 \text { and } 0.5 \mathrm{mg} \mathrm{C} \mathrm{m}^{-3} \mathrm{~d}^{-1} \\
{ }^{e} \text { Computed from oxygen consumption values assuming a respiratory quotient of } 1.25 \mathrm{~mol} \mathrm{O}_{2}\left(\mathrm{~mol} \mathrm{CO}_{2}\right)^{-1} \\
{ }^{\mathrm{f}} \mathrm{C} \text { Computed using a mean respiration rate of } 159 \mu \mathrm{O} \mathrm{O} \mathrm{O}_{2}(\mathrm{mg} \mathrm{DW})^{-1} \text { (Hernández-León 1986) and a respiratory quotient of } \\
1.25 \mathrm{~mol} \mathrm{O}_{2}\left(\mathrm{~mol} \mathrm{CO}_{2}\right)^{-1}\end{array}$} \\
\hline
\end{tabular}

would consume daily an amount of dissolved carbon equivalent to 1 (50\% efficiency) or ca 5 times the average value of primary production (10\% efficiency). The high respiration rates required to explain these estimated consumption values are supported by the results of Arístegui \& Montero (1995), who reported average respiration rates of $18 \mathrm{mg} \mathrm{C} \mathrm{m}^{-3} \mathrm{~d}^{-1}$ for microplankton in Canarian waters (Table 7). Using again extreme efficiency values of 10 and $50 \%$ for bacterial production, the average bacterial carbon production measured in our study would require the respiration of 2 to $11 \mathrm{mg} \mathrm{C} \mathrm{m} \mathrm{m}^{-3}$, that is from 11 to $60 \%$ the average respiration rate of microplankton. Since bacteria are the main components of microplanktonic biomass, it is likely that they are also the main contributors to microplanktonic respiration, assuming that phytoplankton respiration is equivalent to $15 \%$ of particulate primary production (Setchell \& Packard 1979). Therefore, bacterial carbon-conversion efficiencies in Canarian waters must be ca $5 \%$ to ac- count for the measured respiration rates. This low efficiency value concurs with recent estimates explaining bacterial respiration in unproductive ocean waters (del Giorgio et al. 1997, Gasol et al. 1998). However, further studies of carbon fluxes in the Canary Islands region must also include measurements of biomass, production and respiration of heterotrophic flagellates, all of which are important contributors to carbon fluxes and display significant abundances in these waters (Ballesteros 1994).

Another implication of these results is that external sources of dissolved carbon are required to sustain the estimated heterotrophic consumption rates. One of the most immediate sources may be the productive upwelling on the African coast, since there are reports of lateral exports of phytoplankton biomass over large distances (Head et al. 1996, Arístegui et al. 1997). Nevertheless, the importance of bacteria in the carbon budget of oceanic waters around the Canary Islands must be appropriately weighted to the main time 
scales affecting the pelagic ecosystem, since shortterm fluxes may be not balanced as reported in other studies (Pomeroy \& Wiebe 1993). Our preliminary estimations of a carbon budget for the Canarian waters must be confirmed by a seasonal study of planktonic biomass and carbon fluxes, particularly taking into account bacteria and heterotrophic flagellates, and including productive phytoplankton blooms such as those observed during the spring (de León \& Braun 1973, Braun 1980, Real et al. 1981, Braun \& Real 1984, Arístegui et al. 1989, Fernández de Puelles \& Braun 1989, Arístegui 1990) and near cyclonic eddies or coastal sites (Arístegui et al. 1989, 1997).

Acknowledgements. We are grateful to the crew of RV 'Thalassa' and to all participants for their help during the cruise. We would like also to express our thanks for the collaboration of Begoña Castro and Jorge Lorenzo in processing and counting plankton samples in the laboratory, and Josep Gasol, Angeles Cid and Joaquin Valencia for their advice on the measurement of bacterial productivity. J. Arístegui, H. Ducklow and 2 anonymous referees made useful suggestions to a first version of the manuscript. S.B. acknowledges the reception of a PFPI fellowship of the Ministerio de Educación y Ciencia (Spain). This work was supported by project BIOCAN-98 of the Instituto Español de Oceanografía (Spain) and project CANIGO (MAS3-CT96-0060) of the European Union.

\section{LITERATURE CITED}

Arístegui J (1990) La distribución de la clorofila a en aguas de Canarias. Boln Inst Esp Oceanogr 6(2):61-72

Arístegui J, Montero MF (1995) The relationship between community respiration and ETS activity in the ocean. J Plankton Res 17:1563-1571

Arístegui J, Hernández-León S, Gómez M, Medina L, Ojeda A, Torres S (1989) Influence of the north trade winds on the biomass and production of neritic plankton around Gran Canaria Island. Sci Mar 53:223-229

Arístegui J, Sangrá P, Hernández-León S, Cantón M, Hernández-Guerra A, Kerling JL (1994) Island-induced eddies in the Canary Islands. Deep-Sea Res 41:1509-1525

Arístegui J, Tett $P$, Hernández-Guerra A, Basterretxea $G$, Montero MF, Wild K, Sangrá P, Hernández-León S, Cantón M, García-Braun JA, Pacheco M, Barton ED (1997) The influence of island-generated eddies on chlorophyll distribution: a study of mesoscale variation around Gran Canaria. Deep-Sea Res 44:71-96

Ballesteros S (1994) Influencia de las estucturas mesoscalares sobre la distribución y abundancia de bacterias y cianobacterias en aguas de Canarias. PhD thesis, Universidad de Las Palmas de Gran Canaria, Las Palmas

Barquero S, Botas JA, Bode A (1998) Abundance and production of pelagic bacteria in the southern Bay of Biscay during summer. Sci Mar 62:83-90

Binder BJ, Chisholm SW, Olson RJ, Frankell SL, Worden AZ (1996) Dynamics of picophytoplankton, ultraphytoplankton and bacteria in the central equatorial Pacific. DeepSea Res 43:907-931

Bjørnsen PK, Kuparinen J (1991) Determination of bacterioplankton biomass, net production and growth efficiency in the Southern Ocean. Mar Ecol Prog Ser 71:185-194
Braun JG (1974) Estudio preliminar sobre el grado de filtración del zooplancton en aguas canarias. Bol Inst Esp Oceanogr 178:1-12

Braun JG (1980) Estudios de producción en aguas de las Islas Canarias. I. Hidrografía, nutrientes y producción primaria. Boln Inst Esp Oceanogr 285:149-154

Braun JG (1981) Estudios de producción en aguas de las Islas Canarias. II. Producción del zooplancton. Boln Inst Esp Oceanogr 290:89-96

Braun JG, Real F (1981) Algunas comparaciones entre el nanofitoplancton y el fitoplancton de red en aguas de las Islas Canarias. Boln Inst Esp Oceanogr 291:97-105

Braun JG, Real F (1984) Estudios de producción en la bahía de Antequera: una comparación con aguas oceánicas. Boln Inst Esp Oceanogr 1(2):134-140

Braun JG, Real F (1986) Distribución vertical de la clorofila en aguas de las Islas Canarias. Boln Inst Esp Oceanogr 3(2): 97-106

Braun JG, Escánez JE, de León AR (1976) Observaciones químicas y biológicas en el NW de Africa, entre cabo Juby y cabo Ghir (Campaña Cineca-'Cornide de Saavedra', Febrero 1973). Boln Inst Esp Oceanogr 209:1-11

Braun JG, Orzáiz I, de Armas JD, Real F (1985) Productividad y biomasa del ultraplancton, nanoplancton y fitoplancton de red en aguas de las Islas Canarias. Boln Inst Esp Oceanogr 2(1):192-204

Braun JG, de Armas JD, Escánez JE, Real F, Santamaría MTG, Vargas C, Orzáiz I, Villamandos JE (1990) Condiciones oceanográficas en primavera en aguas de la isla de Tenerife. I. Hidrografía y química. Boln Inst Esp Oceanogr 6(2):21-28

Buck KR, Chavez FP, Campbell L (1996) Basin-wide distributions of living carbon components and the inverted trophic pyramid of the central gyre of the North Atlantic Ocean, summer 1993. Aquat Microb Ecol 10:283-298

Campbell L, Nolla HA, Vaulot D (1994) The importance of Prochlorococcus to community structure in the central North Pacific Ocean. Limnol Oceanogr 39:954-961

Carlson CA, Ducklow HW (1996) Growth of bacterioplankton and consumption of dissolved organic carbon in the Sargasso Sea. Aquat Microb Ecol 10:69-85

Carlson CA, Ducklow HW, Sleeter TD (1996) Stocks and dynamics of bacterioplankton in the northwestern Sargasso Sea. Deep-Sea Res (II) 43:491-515

Cho BC, Azam F (1988) Major role of bacteria in biogeochemical fluxes in the ocean's interior. Nature 332:441-443

Cho BC, Azam F (1990) Biogeochemical significance of bacterial biomass in the ocean's euphotic zone. Mar Ecol Prog Ser 63:253-259

Cole JJ, Findlay S, Page M (1988) Bacterioplankton production in fresh and saltwater ecosystems: a cross-system overview. Mar Ecol Prog Ser 33:111-120

Cullen JJ (1982) The deep chlorophyll maximum: comparing vertical profiles of chlorophyll a. Can J Fish Aquat Sci 39: 791-803

de León AR, Braun JG (1973) Ciclo anual de la producción primaria y su relación con los nutrientes en aguas canarias. Boln Inst Esp Oceanogr 167:1-24

del Giorgio PA, Cole JJ, Cimbleris A (1997) Respiration rates in bacteria exceed phytoplankton production in unproductive aquatic systems. Nature 385:148-151

Duarte CM, Agustí S (1998) The $\mathrm{CO}_{2}$ balance of unproductive aquatic systems. Science 281:234-236

Ducklow HW (1993) Bacterioplankton distributions and production in the northwestern Indian ocean and Gulf-ofOman, September 1986. Deep-Sea Res (II) 40:753-771

Ducklow HW, Kirchman DL, Quinby HL, Carlson CA, Dam 
HG (1993) Stocks and dynamics of bacterioplankton during the spring bloom in the eastern North Atlantic Ocean. Deep-Sea Res (II) 40:245-263

Ducklow HW, Quinby HL, Carlson CA (1995) Bacterioplankton dynamics in the equatorial Pacific during the $1992 \mathrm{El}$ Niño. Deep-Sea Res (II) 42:621-638

Fernández de Puelles ML (1987) Evolución anual del microzooplancton en aguas de las Islas Canarias. Boln Inst Esp Oceanogr 4(2):79-90

Fernández de Puelles ML, Braun JG (1989) Dinámica de las comunidades planctónicas en una zona del Atlántico Subtropical (Isla de Tenerife). Boln Inst Esp Oceanogr 5(2): $87-100$

Fernández de Puelles ML, Braun JG (1996) Micro and mesozooplankton in Canarian waters $\left(28^{\circ} 30^{\prime} \mathrm{N}, 16^{\circ} 6^{\prime} \mathrm{W}\right)$. In: Llinás O, González JA, Rueda MJ (eds) Oceanografía y recursos marinos en el Atlántico Centro-Oriental. Gobierno de Canarias. Cabildo de Gran Canaria, p 69-90

Fukuda R, Ogawa H, Nagata T, Koike I (1998) Direct determination of carbon and nitrogen contents of natural bacterial assemblages in marine environments. Appl Envir Microbiol 64:3352-3358

Gasol JM, Doval MD, Pinhassi J, Calderón-Paz JI, GuixáBioxareu N, Vaqué D, Pedrós-Alió C (1998) Diel variations in bacterial heterotrophic activity and growth in the northwestern Mediterranean Sea. Mar Ecol Prog Ser 164: 107-124

Hanson RB, Alvarez-Ossorio MT, Cal R, Campos MJ, Roman M, Santiago G, Varela M, Yoder JA (1986) Plankton response following a spring upwelling event in the Ria de Arosa, Spain. Mar Ecol Prog Ser 32:101-113

Head EJH, Harrison WG, Irwin BI, Horne EPW, Li WKW (1996) Plankton dynamics and carbon flux in an area of upwelling off the coast of Morocco. Deep-Sea Res 43: $1713-1738$

Hernández-León S (1986) Nota sobre la regeneración de amonio por el mesozooplancton en aguas de Canarias. Boln Inst Esp Oceanogr 3(1):75-80

Hernández-León S (1987) Actividad del sistema de transporte de electrones en el mesozooplancton durante un máximo primaveral en aguas del Archipiélago Canario. Invest Pesq 51:491-499

Hernández-León S (1988) Gradients of mesozooplanton biomass and ETS activity in the wind shear area as evidence of an islands mass effect in the Canary Islands waters. J Plankton Res 10:1141-1154

Hernández-León S, Miranda-Rodal D (1987) Actividad del sistema de transporte de electrones y biomasa del mesozooplancton en aguas de las Islas Canarias. Boln Inst Esp Oceanogr 4(2):49-61

Hernández-León S, Torres S (1997) The relationship between ammonia excretion and GDH activity in marine zooplankton. J Plankton Res 19:587-601

Hernández-León S, Llinás O, Braun JG (1984) Nota sobre la variación de la biomasa de mesozooplancton en aguas de Canarias. Invest Pesq 48:495-508

Jumars PA, Penry DL, Baross JA, Perry MJ, Frost B (1989) Closing the microbial loop: dissolved carbon pathway to heterotrophic bacteria from incomplete ingestion, digestion and absorption in animals. Deep-Sea Res 36:483-495

Jones DR, Karl DM, Laws EA (1996) Growth rates and production of heterotrophic bacteria and phytoplankton in the North Pacific subtropical gyre. Deep-Sea Res 43: $1567-1580$

Kirchman DL (1992) Incorporation of thymidine and leucine in the subarctic Pacific: application to estimating bacterial production. Mar Ecol Prog Ser 82:301-309
Kirchman DL (1993) Leucine incorporation as a measure of biomass production by heterotrophic bacteria. In: Kemp PF, Sherr BF, Sherr EB, Cole JJ (eds) Handbook of methods in aquatic microbial ecology. Lewis Publishers, Boca Raton, p 509-512

Kirchman DL (1997) Microbial breathing lessons. Nature 385: $121-122$

Kirchman DL, Ducklow HW (1993) Estimating conversion factors for the thymidine and leucine methods for measuring bacterial production. In: Kemp PF, Sherr BF, Sherr EB, Cole JJ (eds) Handbook of methods in aquatic microbial ecology. Lewis Publishers, Boca Raton, p 513-517

Kroer N (1993) Bacterial growth efficiency on natural dissolved organic matter. Limnol Oceanogr 38:1282-1290

Li WKW (1995) Composition of ultraphytoplankton in the central North Atlantic. Mar Ecol Prog Ser 122:1-8

Li WKW, Dickie PM, Harrison WG, Irwin BD (1993) Biomass and production of bacteria and phytoplankton during the spring bloom in the western North Atlantic Ocean. DeepSea Res (II) 40:307-323

McManus GB, Dawson R (1994) Phytoplankton pigments in the deep chlorophyll maximum of the Caribbean Sea and the western tropical Atlantic Ocean. Mar Ecol Prog Ser 113:199-206

Norland S, Heldal M, Tumyr O (1987) On the relation between dry matter and volume of bacteria. Microb Ecol 13: 95-103

Ojeda A (1996) Biomasa fitoplanctónica y clorofila a en las Islas Canarias Occidentales. Mayo 1986. In: Llinás O, González JA, Rueda MJ (eds) Oceanografía y recursos marinos en el Atlántico Centro-Oriental. Gobierno de Canarias, Cabildo de Gran Canaria, p 91-121

Parsons TR, Maita Y, Lalli CM (1984) A manual of chemical and biological methods for seawater analysis. Pergamon Press, Oxford

Pomeroy LR, Wiebe WJ (1993) Seasonal uncoupling of the microbial loop and its potential significance for the global cycle of carbon. In: Guerrero R, Pedrós-Alió C (ed) Trends in microbial ecology. Sociedad Española de Microbiología, Barcelona, p 407-409

Pomeroy LR, Sheldon JE, Sheldon WM, Peters F (1995) Limits to growth and respiration of bacterioplankton in the Gulf of Mexico. Mar Ecol Prog Ser 117:259-268

Porter KG, Feig YS (1980) The use of DAPI for identifying and counting aquatic microflora. Limnol Oceanogr 25:943-948

Real F, de Armas JD, Braun JG (1981) Distribución espacial de la clorofila a y del carbono orgánico particulado en aguas costeras superficiales de las Islas Canarias. Boln Inst Esp Oceanogr 292:109-115

Setchell FW, Packard TT (1979) Phytoplankton respiration in the Peru upwelling. J Plankton Res 1:343-354

Shiah FK, Ducklow HW (1994) Temperature regulation of heterotrophic bacterioplankton abundance, production, and specific growth rate in Chesapeake Bay. Limnol Oceanogr 39:1243-1258

Sieracki ME, Haugen EM, Cucci TL (1995) Overestimation of heterotrophic bacteria in the Sargasso Sea: direct evidence by flow and imaging cytometry. Deep-Sea Res 42:1399-1409

Simon M, Azam F (1989) Protein content and protein synthesis rates of planktonic marine bacteria. Mar Ecol Prog Ser 51:201-213

Simon M, Welschmeyer NA, Kirchman DL (1992) Bacterial production and the sinking flux of particulate organic matter in the subarctic Pacific. Deep-Sea Res 39:1997-2008

Smith DC, Azam F (1992) A simple, economical method for measuring bacterial protein synthesis rates in seawater using ${ }^{3} \mathrm{H}$-leucine. Mar Microb Fd Webs 6:107-114 
Tenore KR, Alonso-Noval M, Alvarez-Ossorio, M, Atkinson LP, Cabanas JM, Cal RM, Campos HJ, Castillejo F, Chesney EJ, Gonzalez N, Hanson RB, McClain CR, Miranda A, Roman MR, Sanchez J, Santiago G, Valdes L, Varela M, Yoder J (1995) Fisheries and oceanography off Galicia, NW Spain: mesoscale spatial and temporal changes in physical processes and resultant patterns of biological production. J Geophys Res 100:10943-10966

Toggweiler JR (1989) Is the downward dissolved organic matter (DOM) flux important in carbon transport? In: Berger WH, Smetacek VS, Wefer G (eds) Productivity of the ocean: present and past. Wiley, New York, p 65-83

Watson SW (1978) Role of bacteria in an upwelling ecosystem. In: Boje R, Tomczak $M$ (eds) Upwelling ecosystems. Springer-Verlag, Berlin, p 139-154

Editorial responsibility: Otto Kinne (Editor), Oldendorf/Luhe, Germany
White PA, Kalff J, Rasmussen JB, JM Gasol (1991) The effect of temperature and algal biomass on bacterial production and specific growth rate in freshwater and marine habitats. Microb Ecol 21:99-118

Wiebe PH (1988) Functional regression equations for zooplankton displacement volume, wet weight, dry weight, and carbon: a correction. Fish Bull US 86:833-835

Williams PJ LeB (1998) The balance of plankton respiration and photosynthesis in the open ocean. Nature 394:55-57

Wood AM, Rai H, Garnier J, Kairesalo T, Gresens S, Orive E, Ravail B (1992) Practical approaches to algal excretion. Mar Microb Fd Webs 6:21-38

Zubkov MV, Sleigh MA, Tarran GA, Burkill PH, Leakey RJG (1998) Picoplankton community structure on an Atlantic transect from $50^{\circ} \mathrm{N}$ to $50^{\circ} \mathrm{S}$. Deep-Sea Res 45:1339-1355

Submitted: December 17, 1999; Accepted: April 10, 2000 Proofs received from author(s): December 18, 2000 